\title{
Pierwotne i wtórne zapalenia naczyń układu nerwowego
}

\section{Primary and secondary nervous system vasculitis}

\author{
Paweł Wańkowicz ${ }^{1 凶}$, Przemysław Nowacki ${ }^{1}$, Marek Brzosko² \\ 1 Pomorski Uniwersytet Medyczny w Szczecinie, Katedra i Klinika Neurologii, ul. Unii Lubelskiej 1, 71-252 Szczecin \\ Pomeranian Medical University in Szczecin, Department and Clinic of Neurology \\ ${ }^{2}$ Pomorski Uniwersytet Medyczny w Szczecinie, Klinika Reumatologii, Chorób Wewnętrznych i Geriatrii, ul. Unii Lubelskiej 1, 71-252 Szczecin \\ Pomeranian Medical University in Szczecin, Department of Rheumatology, Internal Medicine and Geriatrics \\ $\triangle$ pawelwankowicz@gmail.com
}

\begin{abstract}
Central and peripheral nervous system vascular disorders are a heterogeneous group of diseases, divided into primary and secondary inflammations. In primary vasculitis, the lesions are limited to the nervous system, without inflammatory changes in the vessels of other organs. In secondary vasculitis the nervous system vasculitis accompanies systemic diseases. Nervous system vasculitis is associated with a variety of neurological
\end{abstract}

\section{ABSTRAKT}

Zapalenia naczyń ośrodkowego i obwodowego układu nerwowego stanowią heterogenną grupę chorób. Dzieli się je na zapalenia pierwotne i wtórne. W pierwotnych zapaleniach naczyń zmiany ograniczają się do układu nerwowego, bez zmian zapalnych w naczyniach innych narządów. Jako wtórne natomiast określa się zapalenia naczyń, w których zajęcie układu nerwowego towarzyszy chorobom ogólnoustrojowym. W przebiegu symptoms and their combinations, which makes diagnosis difficult.

The aim of this publication is to review the current neurological symptomatology and the diagnostic and therapeutic possibilities in the treatment of vasculitis.

Keywords: primary vasculitis; secondary vasculitis; nervous system.

zapalenia naczyń układu nerwowego występuje różnorodność objawów neurologicznych i ich kombinacje, co sprawia, że są trudne do rozpoznania.

Celem niniejszej publikacji był przegląd aktualnej symptomatologii neurologicznej oraz możliwości diagnostycznych i terapeutycznych w przebiegu zapalenia naczyń układu nerwowego. Słowa kluczowe: pierwotne zapalenia naczyń; wtórne zapalenia naczyń; układ nerwowy.

\section{WSTĘP}

Zapalenia naczyń układu nerwowego stanowią heterogenną grupę chorób. Dzieli się je na zapalenia pierwotne i wtórne. W pierwotnych zapaleniach naczyń zmiany ograniczają się do układu nerwowego, bez zmian zapalnych w naczyniach innych narządów. Jako wtórne natomiast określa się zapalenia naczyń, w których zajęcie układu nerwowego towarzyszy chorobom ogólnoustrojowym. Zarówno w pierwotnych, jak i wtórnych zapaleniach naczyń układu nerwowego głównym powodem wystąpienia objawów klinicznych jest niedokrwienie $[1,2]$.

W przebiegu zapalenia naczyń układu nerwowego występują różnorodne objawy neurologiczne jako odzwierciedlenie ogniskowego, wieloogniskowego lub rozlanego uszkodzenia układu nerwowego [3]. Najczęstszymi objawami są bóle głowy, ogniskowe lub uogólnione napady padaczkowe, przemijające ataki niedokrwienia mózgu, udary niedokrwienne lub krwotoczne, zaburzenia funkcji poznawczych, neuropatie obwodowe i neuropatie nerwów czaszkowych [4]. Przebieg kliniczny może być ostry, podostry lub przewlekły z okresami zaostrzeń i remisji. Różnorodność objawów neurologicznych i ich kombinacji sprawia, że zapalenia naczyń układu nerwowego są trudne do rozpoznania [5].

W praktyce klinicznej w rozpoznaniu zapaleń naczyń układu nerwowego pomocne są badania neuroobrazowe, w tym wizualizacja małych naczyń mózgowych. Podejrzenie zapalenia naczyń układu nerwowego, wsparte neuroobrazowaniem, wymaga rozszerzenia panelu badań zmierzających do wykrycia podłoża immunologiczno-zapalnego obserwowanych objawów neurologicznych. Wyniki badań płynu mózgowo-rdzeniowego zwykle nie są charakterystyczne, o ile w ogóle wypadają nieprawidłowo, dlatego w dalszym ciągu złotym standardem diagnostycznym jest biopsja mózgu [6].

\section{PIERWOTNE ZAPALENIE NACZYŃ OŚRODKOWEGO UKŁADU NERWOWEGO}

Pierwotne zapalenie naczyń ośrodkowego układu nerwowego (primary angitis of the central nervous system - PACNS) jest bardzo rzadkim schorzeniem, które prawie wyłącznie 
ogranicza się do mózgowia, rzadziej obejmuje rdzeń kręgowy. Histologicznie zapalenie może mieć charakter ziarniniakowy, martwiczy, limfocytarny lub mieszany. Niektórzy autorzy zaliczają ten typ zapalenia do ziarniniakowych zapaleń naczyń. Etiopatogeneza tego schorzenia nie jest znana. Pod uwagę bierze się czynniki infekcyjne lub zakaźne. Duna i wsp. [7] wykazali związek PACNS z zaburzeniami takimi jak ziarnica złośliwa, chłoniaki nieziarnicze, zespół Sjögrena, zakażenia wirusowe HIV, HTLV. U niektórych chorych stwierdza się zmiany o charakterze angiopatii amyloidowej. Pierwotne zapalenie naczyń ośrodkowego układu nerwowego może wystąpić w każdym wieku, ale najczęściej dotyka pacjentów w średnim wieku, z niewielką przewagą mężczyzn (4:3). Obraz kliniczny nie jest typowy. Objawy kliniczne rozwijają się zwykle kilka tygodni, w sposób stopniowy. Podejrzenie choroby wzrasta, jeżeli obserwowane są bóle głowy, zmiana stanu psychicznego, napady padaczkowe czy objawy rdzeniowe. Nie towarzyszą im objawy układowe i wzrost parametrów stanu zapalnego, aczkolwiek w pojedynczych publikacjach odnotowano również zajęcie tętnic płucnych oraz naczyń narządów jamy brzusznej. Rozpoznanie PACNS wykluczają objawy narządowe. Rozpoznanie pierwotnego zapalenia naczyń ośrodkowego układu nerwowego (OUN) można ustalić na podstawie objawów klinicznych, badań neuroobrazowych, uzupełnionych o cyfrową angiografię subtrakcyjną (digital subtraction angiography - DSA), a także w badaniu histopatologicznym biopsji mózgu. W badaniu tomografii rezonansu magnetycznego (magnetic resonance imaging - MRI) stwierdza się zmiany niedokrwienne, krwotoczne, o charakterze leukoencefalopatii, jak również wzmocnienie opon miękkich. W DSA naczyń mózgowych występują zwykle obustronne przewężenia lub zamknięcia naczyń jako następstwo procesu zapalnego ściany naczyniowej [8]. U większości chorych w badaniu płynu mózgowo-rdzeniowego stwierdza się niespecyficzną pleocytozę i podwyższone stężenie białka. Z uwagi na rzadkość występowania PACNS obecnie brak jest jednoznacznych i ustalonych schematów leczenia tego schorzenia. Zwykle stosuje się bardzo zbliżone schematy leczenia jak w chorobach tkanki łącznej przebiegających z zajęciem OUN, tj. glikokortykosteroidy i cyklofosfamid. Rokowanie w przypadku PACNS jest niepomyślne, gdyż większość pacjentów umiera w ciągu roku od rozpoznania $[9,10]$.

\section{POWIKŁANIA NEUROLOGICZNE UKŁADOWYCH ZAPALEŃ NACZYŃ}

Manifestacja neurologiczna, poza pierwotnym (izolowanym) zapaleniem naczyń, należy także do obrazu klinicznego układowych zapaleń naczyń/układowych chorób tkanki łącznej. Najczęściej powikłania neurologiczne występują w toczniu rumieniowatym układowym, niemniej jednak pojawiają się one także w innych chorobach. Poza toczniem rumieniowatym układowym, w którym występują zaburzenia psychiczne i somatyczne ze strony OUN (neurotoczeń), typowymi dla tocznia, choć nie patognomicznymi, manifestacja neurologiczna wynikająca z wtórnego zapalenia naczyń mózgowych nie jest specyficzna. Rozpoznanie stawiane jest w kontekście choroby podstawowej.

\section{Toczeń rumieniowaty układowy}

Toczeń rumieniowaty układowy (systemic lupus erythematosus - SLE) jest chorobą o podłożu autoimmunologicznym. Jego występowanie ocenia się na ok. 40-50 przypadków na 100000 osób. Osiem razy częściej dotyka kobiety. Pierwsza adnotacja na temat objawów neurologicznych w SLE sięga 1872 r. W przebiegu SLE mogą wystąpić różnorodne objawy neurologiczne i psychiatryczne, które prowadzą do rozpoznania formy neuropsychiatrycznej SLE. Określane są one też mianem neurotoczeń. Powikłania neurologiczne są wynikiem aktywności autoimmunologicznej w obrębie ośrodkowego i obwodowego układu nerwowego. Rozwijają się u ok. 60-75\% chorych na SLE. Neuropsychiatryczna forma SLE może być pierwszą manifestacją choroby, wynikać z powikłań choroby lub być następstwem leczenia. Komitet badawczy American College of Rheumatology stworzył listę 19 najbardziej charakterystycznych dla neurotocznia zespołów neuropsychiatrycznych, m.in.: ostry stan splątania, zaburzenia nastroju, aseptyczne zapalenie opon mózgowo-rdzeniowych, mózgowy zespół naczyniowy, zaburzenia funkcji poznawczych, bóle głowy, neuropatia nerwów czaszkowych, psychoza, drgawki [11]. Postawienie rozpoznania neurotocznia nie jest łatwe, gdyż często nawet biopsja mózgu nie jest pomocna. Rutynowe postępowanie powinno obejmować badanie neurologiczne, nakłucie lędźwiowe w celu pobrania i zbadania płynu mózgowo-rdzeniowego pod kątem parametrów zapalnych, elektroencefalografię, jak również nowoczesne metody obrazowania, jak MRI oraz pozytronowa tomografia emisyjna (positron emission tomography - PET), które są bardzo pomocne w wykrywaniu wszelkiego rodzaju zmian w mózgowiu i rdzeniu kręgowym. Wyniki nie są jednak swoiste, gdyż wymagają interpretacji w połączeniu z całym obrazem klinicznym [12]. Leczenie podstawowe jest takie same w przypadkach zmian zarówno w ośrodkowym, jak i obwodowym układzie nerwowym. Obecnie w terapii neurotocznia stosuje się steroidoterapię w wysokich dawkach i cyklofosfamid [13, 14].

\section{Ziarniniakowatość z zapaleniem naczyń}

Choroba charakteryzuje się martwiczym ziarniniakowym zapaleniem małych naczyń. Może wystąpić w każdym wieku i dotyczy obu płci, aczkolwiek mężczyźni chorują częściej (2:1). Zajęcie układu nerwowego obserwuje się u ok. 35\% wszystkich pacjentów. Dominują mononeuropatia wieloogniskowa i polineuropatia jako efekt zajęcia obwodowego układu nerwowego. Zajęcie OUN występuje znacznie rzadziej. Przejawia się ono udarami niedokrwiennymi bądź krwotocznymi oraz neuropatią nerwów czaszkowych o różnej konfiguracji. Najczęściej jednak dochodzi do uszkodzenia nerwu twarzowego i przedsionkowo-ślimakowego, co jest efektem nacieku zapalnego na piramidę kości skroniowych, zapalenia naczyń w obrębie ucha środkowego i wewnętrznego [15]. W wykrywaniu patologii w obrębie ośrodkowego i obwodowego układu 
nerwowego bardzo pomocne są badania MRI oraz elektromiograficzne. Wyniki badania płynu mózgowo-rdzeniowego zwykle nie są charakterystyczne. Chorobę we wczesnej postaci można leczyć od początku metotreksatem, a w przypadku wystąpienia zajęcia narządów lub zagrożenia życia należy zastosować cyklofosfamid. Można również stosować leki biologiczne, jak infliksymab, adalimumab, etanercept, tocylizumab czy rytuksymab. Obecnie prowadzone są badania kliniczne, które powinny ustalić wskazania do stosowania rytuksymabu i tocylizumabu $[16,17]$.

\section{Mikroskopowe zapalenie naczyń}

Mikroskopowe zapalenie naczyń przebiega z zajęciem małych naczyń krwionośnych. Zajęcie układu nerwowego spotyka się u ok. 50\% wszystkich pacjentów. Dominuje zajęcie obwodowego układu nerwowego o charakterze mononeuropatii lub mononeuropatii mnogiej. Bardzo rzadko dochodzi do zajęcia OUN. Przejawia się ono udarami niedokrwiennymi oraz neuropatią nerwów czaszkowych o różnej konfiguracji [18].

\section{Guzkowe zapalenie tętnic}

Jest to choroba zapalna małych i średnich tętnic. Proces zapalny może obejmować cały obwód naczynia, co w konsekwencji prowadzi do zwężenia lub zamknięcia jego światła. Zajęcie układu nerwowego obserwuje się u ok. 50-60\% pacjentów. Choroba ta może mieć bardzo bogatą manifestację neurologiczną, głównie jednak ze strony obwodowego układu nerwowego. Ze strony OUN obserwowane są neuropatia nerwów czaszkowych (najczęściej zajęte bywają nerwy: wzrokowy, twarzowy, przedsionkowo-ślimawkowy), udary niedokrwienne lub krwotoczne, rozlana encefalopatia, aseptyczne zapalenie opon mózgowo-rdzeniowych i mózgu, objawy pozapiramidowe naśladujące zespół parkinsonowski z dominującą plastycznością i bradykinezją, a ponadto objawy rdzeniowe [1,5].

W badaniu MRI mózgowia stwierdza się obecność hiperintensywnych ognisk w korze, strukturach podkorowych, zwojach podstawy, pniu mózgu i móżdżku. W badaniu DSA naczyń mózgowych można uwidocznić zaburzenia przepływu w zajętych naczyniach, jak również obecność tętniaków workowatych i wrzecionowatych. Badanie płynu mózgowo-rdzeniowego zazwyczaj jest prawidłowe [6].

\section{Olbrzymiokomórkowe zapalenie tętnic}

Jest przewlekłą zapalną chorobą średnich i dużych tętnic dotykającą głównie kobiety po menopauzie. Cechą charakterystyczną tej choroby jest występowanie w błonie środkowej tętnic wielojądrzastych komórek olbrzymich. Do objawów choroby zalicza się ból głowy zlokalizowany w obszarze zaopatrywanym przez zmienioną chorobowo tętnicę skroniową. Zajęta tętnica skroniowa może być wyczuwalna, tkliwa i niepodatna na ucisk. U ok. 30\% chorych może wystąpić jednostronna ślepota spowodowana przez zamknięcie światła tętnicy środkowej siatkówki [19, 20]. Tarcza nerwu wzrokowego może być prawidłowa, blada lub obrzęknięta, z krwotokami na powierzchni siatkówki. Często spotyka się również epizody naczyniowe (przejściowe ataki niedokrwienne lub udary niedokrwienne) oraz uszkodzenie nerwów gałkoruchowych. Rzadko dochodzi do zajęcia innych nerwów czaszkowych. Może być również przyczyną rzadko obserwowanych odwracalnych zaburzeń poznawczych i zespołów neuropsychiatrycznych. W diagnostyce wykorzystuje się badanie USG metodą Dopplera, które wymaga dużego doświadczenia i dobrego wyszkolenia lekarzy wykonujących. Swoistość diagnostyczna patognomicznego objawu „halo” sięga 100\%, jednak objaw ten występuje niestety dość rzadko. Badania MRI lub PET zarezerwowane są jedynie dla przypadków zajęcia dużych naczyń lub obecności powikłań z ich strony. Natomiast w dalszym ciągu złotym standardem do postawienia rozpoznania olbrzymiokomórkowego zapalenia tętnicy jest wykonanie biopsji tętnicy skroniowej powierzchownej. W leczeniu stosuje się glikokortykosteroidy oraz w małej dawce kwas acetylosalicylowy [21].

\section{Choroba Takayasu}

Choroba Takayasu zwana jest także chorobą bez tętna i zazwyczaj dotyczy młodych kobiet. Zapalenie obejmuje duże tętnice, głównie łuku aorty i jej odgałęzień, a także proksymalne odcinki naczyń wieńcowych, tętnic nerkowych i sprężystych tętnic płucnych. Do klasycznych objawów należą: zaniki mięśniowe w obrębie kończyn górnych, twarzy, zanik tętna, niskie lub nieoznaczalne ciśnienie tętnicze. Na uwagę zasługuje również różnica ciśnienia tętniczego na kończynach górnych. W ostrej fazie choroby pacjenci zgłaszają ból w okolicy tętnicy szyjnej; pojawiają się także objawy chromania kończyn. Do tego dołączają epizody wynikające z niedokrwienia pod postacią omdleń, zaburzeń widzenia oraz świadomości [22]. Charakterystyczny jest obraz dna oka, w którym można stwierdzić mikrotętniaki, anastomozy tętniczo-żylne w okolicy tarczy nerwu wzrokowego, krwotoki do siatkówki oraz zanik nerwu wzrokowego. Pomocnymi badaniami w ustaleniu rozpoznania są badania obrazowe, takie jak: tomografia komputerowa, pozytronowa emisyjna tomografia, tomografia rezonansu magnetycznego, USG dopplerowskie i angiografia. Pozwalają one ocenić wielkość i rozmieszczenie zmian, a angiografia umożliwia ocenę stanu tętnic, co pomaga w doborze właściwego leczenia. Podstawowym sposobem leczenia jest farmakoterapia, w której lekiem pierwszego rzutu są glikokortykosteroidy. Tym sposobem leczenia uzyskuje się remisję u ok. $60 \%$ chorych, ale nawroty występują u ponad 50\% pacjentów. W związku z tym, że leczenie glikokortykosteroidami nie jest bardzo skuteczne, chorzy wymagają stosowania innych leków immunosupresyjnych. Dobre wyniki uzyskiwano, stosując m.in. metotreksat, leflunomid, azatioprynę, mykofenolan mofetylu czy cyklofosfamid. Rola leków antyagregacyjnych pozostaje niejasna. Kwalifikowanie pacjentów do procedur rewaskularyzacyjnych powinno być ostrożne. Zabiegi najlepiej wykonywać w okresie remisji [23].

Inne układowe choroby zapalne naczyń, np. zespół Churga i Strauss, występują rzadko, a ponadto powikłania ze strony OUN nie należą do ich typowego obrazu klinicznego. Powikłania te nie mają też cech wyróżniających je na tle deficytów neurologicznych w innych rodzajach zapaleń naczyń. 


\section{PODSUMOWANIE}

Zapalenia naczyń z zajęciem układu nerwowego stanowią bardzo różnorodną grupę schorzeń, których diagnostyka jest trudna i wymaga współpracy wielu specjalistów, a w szczególności reumatologa i neurologa. Leczenie w głównej mierze opiera się na stosowaniu glikokortykosteroidów i leków immunosupresyjnych. Dostępne badania, takie jak USG dopplerowskie, tomografia komputerowa, tomografia rezonansu magnetycznego, elektromiografia czy badanie płynu mózgowo-rdzeniowego, są pomocne, ale w większości przypadków niespecyficzne. Dlatego aktualnie złotym standardem w postawieniu rozpoznania zapalenia naczyń z zajęciem układu nerwowego jest biopsja nerwu, opon mózgowo-rdzeniowych lub mózgu.

\section{PIŚMIENNICTWO}

1. Scolding NJ, Jayne DR, Zajicek JP, Meyer PA, Wraight EP, Lockwood CM. The syndrome of cerebral vasculitis: recognition, diagnosis and management. Quarterly J Med 1997;90:61-73.

2. Watts RA, Scott DG. Classification and epidemiology of the vasculitides. Baillieres. Clin Rheumatol 1997;11:191-217.

3. Adams HP Jr. Cerebral vasculitis. Handb Clin Neurol 2014;119:475-94.

4. Berlit P. Diagnosis and treatment of cerebral vasculitis. Ther Adv Neurol Disord 2010;1:29-42.

5. Minagar A, Fowler M, Harris MK, Jaffe SL. Neurologic presentations of systemic vasculitides. Neurol Clin 2010;28:171-84.

6. Younger DS. Vasculitis of the nervous system. Curr Opin Neurol 2004;17:317-36.

7. Duna GF, George T, Rybicki L, Calabrese LH. Primary angitis of the central nervous system (PACNS): an analysis of unusual presentations. Arthritis Rheum 1995;38:S340.

8. Hajj-Ali RA, Singhal AB, Benseler S, Molloy E, Calabrese LH. Primary angitis of the CNS. Lancet Neurol 2011;10:561-72.
9. Calabrese LH, Gragg LA, Furlan AJ. Benign angiopathy: a subset of angiographically defined primary angitis of the central nervous system. J Rheumatol 1993;20:2046-50.

10. Hermann DM, Keyvani K, van de Nes J, Weimar C, Wiltfang J, Nitsch RM, et al. Brain-reactive beta-amyloid antibodies in primary CNS angiitis with cerebral amyloid angiopathy. Neurology 2011;77:503-5.

11. D'Cruz DP, Khamashta MA, Hughes GR. Systemic lupus erythematosus. Lancet 2007;369:587-96.

12. West SG. Lupus and the central nervous system. Curr Opin Rheumatol 1996;8:408-14.

13. Bockie BC, Jara D, Aichhorn K, Junker D, Berger T, Ratzinger G, et al. Cerebral large vessel vasculitis in systemic lupus erthematosus. Lupus 2014;23:1417-21.

14. Fiedorowicz-Fabrycy I, Brzosko M. Diagnostyka powikłań neuropsychiatrycznych w chorobach naczyniowych mózgu w układowych chorób tkanki łącznej. Reumatologia 2005;43:369-72.

15. Jennette JC. Nomenclature and classification of vasculitis: lesson learned from granulomatosis with polyangitis (Wegener's granulomatosis). Clin Exp Immunol 2011;164:7-10.

16. Nardone R., Lochner P, Tezzon F. Wegener's granulomatosis presenting with intracerebral hemorrhages. Cerebrovasc Dis 2004;17:81-2.

17. Nishino H, Rubino FA, DeRemee RA, Swanson JW, Parisi JE. Neurological involvement in Wegener's granulomatosis: an analysis of 324 consecutive patients at the Mayo Clinic. Ann Neurol 1993;33(1):4-9.

18. Guillevin L, Durand-Gasselin B, Cevallos R, Gayraud M, Lhote F, Callard P, et al. Microscopic polyangitis: clinical and laboratory findings in eightyfive patients. Arthritis Rheum 1999;42:421-30.

19. Laria A, Lurati A, Scarpellini M. Color duplex ultrasonography findings of temporal arteries in a case of giant cell arteritis: role in diagnosis and follow-up. Open Access Rheumatol 2017;9:55-9. doi: 10.2147/OARRR. S110585.

20. Rondeau M, Weber J, Storck D. A case of giant cell arteritis associated with suspected cerebral angitis. Eur J Intern Med 2001;12(5):459-61.

21. Salvarani C, Hunder GG. Giant cell arteritis with low erythrocyte sedimentation rate: frequency of occurrence in a population-based Study. Arthritis Rheum 2001;45:140-5.

22. Li-Xin Z, Jun N, Shan G, Bin P, Li-Ying C. Neurological manifestations of Takayasu arteritis. Chin Med Sci J 2011;26:227-30.

23. Pereira VC, de Freitas CC, Luvizutto GJ, Sobreira ML, Peixoto DE, Magalhaes IN, et al. Stroke as the First Clinical Manifestation of Takayasu's Arteritis. Case Rep Neurol 2014;6:271-4. 